International Journal of Environment, Agriculture and Biotechnology
Vol-6, Issue-3; May-Jun, 2021
Journal Home Page Available: $\underline{\text { https://ijeab.com/ }}$
Journal DOI: $\underline{10.22161 / \text { ijeab }}$

Article

Peer-Reviewed Journal

\title{
Extent of Compliance and Perception of Mothers on Childhood Immunization in Barangay Ugac Sur, Tuguegarao City, Philippines: A Descriptive Study
}

\author{
Tito A. Addun, Jr.*, Marilyn B. Martinez, Deniz Marie G. Felix, Marfelle Czarina H. \\ Sayoc
}

School of Medicine, St. Paul University Philippines, Philippines

${ }^{*}$ Corresponding Author

Received: 11 May 2021; Received in revised form: 08 Jun 2021; Accepted: 18 Jun 2021; Available online: 27 Jun 2021 (C)2021 The Author(s). Published by Infogain Publication. This is an open access article under the CC BY license (https://creativecommons.org/licenses/by/4.0/).

\begin{abstract}
This study aimed to determine the extent of compliance of mothers to immunization of their children and the perception of mothers on Expanded Program for Immunization (EPI). Cross-sectional Study, Descriptive. A total of 50 mothers with child or children <5 years of age in Barangay Ugac Sur, Tuguegarao City, Philippines was included in the study. A self-administered semi-structured questionnaire was used. Descriptive statistical tools were utilized to characterize the study population. Fisher's exact test was employed to find out significant association between categorical variables. A p-value $<0.05$ was considered statistically significant. The mean age of respondents was $32 \pm 7.19$ years old. Ninety-four percent (94\%) of the respondents were compliant and 6\% were non-compliant. Non-compliance was attributed to conflict of schedule. Among the categorical variables, only the employment status and the place of vaccination were significantly associated with the extent of compliance of the mothers to childhood immunization. The proportion of compliant mothers who brought their children to Health center $(82 \%)$ was significantly higher (p-value $<0.05)$ than the proportion of compliant mothers who brought their children to private clinics (18\%). Majority of the respondents had their children's vaccination at the health center, while only a few mothers opted to bring their children in private clinics for the routine vaccination of their children. The respondents gave the highest rating on the perception that giving immunization at the right time is more effective in strengthening the immune system of their children, and that there is little to no risk of an epidemic if children have been immunized. Majority of the mothers were compliant to their children's vaccination, and viewed immunization as an important preventive strategy for their children.
\end{abstract}

Keywords-EPI, public health, vaccine, vaccine-preventable disease.

\section{INTRODUCTION}

Immunization is an established tool for the control and elimination of fatal infectious diseases. It is estimated to prevent about 2 to 3 million deaths each year (WHO, 2008). It is considered to be one of the greatest achievements of the 20th century because it has led to the eradication of smallpox in 1977, the dropped in the incidence of poliomyelitis by $99 \%$ since 1988, the elimination of measles in the Western Hemisphere, and the decreased in the measles mortality by about $68 \%$ globally from 2000 to 2006 (WHO, 2008).

In the routine childhood immunization in the Philippines, several vaccines were included to target infectious diseases such as tuberculosis, hepatitis B infection, diphtheria, pertussis, tetanus, poliomyelitis, measles. These vaccines 
protect children from serious illnesses and complications of vaccine-preventable diseases (WHO, 2008).

In the Philippines, 9 out of 10 children aged 12 to 23 months have received basic vaccinations, namely, BCG, measles, DPT, and polio vaccines (PSA 2013). The Philippine Statistics Authority (PSA) reported in 2013 that those children belonging in poor households are less likely to be vaccinated against the preventable childhood diseases compared to those who belong in non-poor households.

In 2019, the Philippines was in the midst of a measles crisis. According to UNICEF-WHO Philippines (2019), a total of 18553 measles cases, including 286 deaths, were reported from January 1 to March 7 2019. Out of this number, 248 were from Cagayan Valley Region. It was also reported that $60 \%$ of all measles cases were not vaccinated (UNICEF-WHO Philippines 2019).

Despite the availability and accessibility of vaccines, people often delay or refuse vaccines for their children. This matter is a growing challenge for countries that are seeking to close the immunization gap. Worldwide data show that 1 out of 5 children are not getting routine lifesaving immunizations, and that about 1.5 million children still die each year due to vaccine-preventable diseases (WHO, 2015).

Parent's role in immunization is crucial. This is so because they act as proxy decision-makers for their children (Damnjanovic et al 2018). It is therefore important to deal with the mother's compliance to their children's vaccination. However, there are only limited studies about the compliance of mothers to childhood immunization. In the study of Alfred and Alfred (2012) in Nigeria, 56\% of the respondents had a high participation to EPI. Majority of their respondents had favorable attitude towards EPI and perceived it as important. It was also noted that age, marital status, household size and religion had significant relationship with the respondents' perception towards EPI. With the scarcity of local data, the researchers of this study delved on the determination of the compliance of the mothers and their perception towards childhood immunization. Additionally, this paper hoped to use the obtained data to address non-compliance to vaccination to further improve the health status of the community.

\subsection{Objectives of the Study}

In general, this study aimed to determine the perception of mothers in Barangay Ugac Sur, Tuguegarao City about the Expanded Program for Immunization (EPI).

Specifically, it sought to determine the following:

a) Profile of the mothers with regards to Marital Status, Educational attainment, Monthly income of the family, Number of Children, Occupation, and Type of Family b) Significant correlation between the profile of the mothers and the compliance status of the respondents

c) Extent of compliance of mothers to immunization of their children;

d) Perception of mothers on the Expanded Program for Immunization (EPI) in terms of Health promotion, Disease prevention, and Reduction in Morbidity or Mortality.

\section{METHODOLOGY}

\subsection{Study Design}

The researchers used a Cross-sectional Descriptive Type of Research Design. It is a self-reported data which was collected from the respondents to explore and describe the perception of mothers toward childhood immunization and the extent of compliance to immunization. In this study, convenience sampling was done to determine the respondents, and only those who satisfied the inclusion criteria were included in the study.

\subsection{Research Locale}

The study was conducted in Barangay Ugac Sur, Tuguegarao City. The researchers chose this barangay because, out of 49 barangays in Tuguegarao City, Cagayan, Philippines, this community caters the largest population.

\subsection{Respondents of the Study}

The respondents of the study were the mothers in Barangay Ugac Sur, Tuguegarao City, Cagayan, Philippines. A convenience sampling of 50 mothers was done in this study. Only those who satisfied the following inclusion criteria were included in the study:

a) A mother

b) A resident of Barangay Ugac Sur, Tuguegarao City

c) Has a child or children <5 years of Age

\subsection{Instrumentation}

The data gathering instrument that the researchers used was a self-administered semi-structured questionnaire that is based on the study of Castillo and colleagues (2014) entitled "Extent of Compliance to Immunization: Reasons for Non-continuity and Its Consequences," which was administered in Barangay Darasa, Tanauan, Batangas.

The questionnaire was composed of two parts. The first part was about the profile of the respondents, which include marital status, number of children, educational attainment, monthly income, type of family, and occupation. Also included in the first part were the compliance of the respondents to vaccination and the place of vaccination. The second part of the questionnaire included questions regarding the perception of mother about the expanded program on immunization (EPI). 


\subsection{Data Gathering Procedure}

Prior to the conduct of the study, request letters addressed to the City Health Office and the Barangay Council of Ugac Sur, Tuguegarao City were given to allow the researchers to gather preliminary data from the Barangay Health Center in Ugac Sur, Tuguegarao City and to acquire the list of mothers who have children in need of immunizations.

The researchers personally distributed the questionnaires, and interviewed and assisted the target respondents. After which, accomplished questionnaires were retrieved, and raw data were statistically evaluated.

\subsection{Ethical Consideration}

The study was approved by the review panel of the School of Medicine of St. Paul University Philippines, Tuguegarao City, Cagayan, Philippines. In addition, pertinent consent form and information sheet were integrated in the data collection sheet. All of the respondents were clearly informed about the objectives as well as the significance of the study. Finally, informed consent was obtained before the conduct of the interview.

\subsection{Data Analysis}

The statistical analysis of the data obtained in this study was done through Microsoft Excel and SPSS version 22. The researchers used appropriate statistical tools to ensure valid and reliable analysis and interpretation of data. Frequency distribution, Percentage distribution, and Measures of Central Tendency were utilized. Fisher's exact test was used to find out significant association between categorical variables. The "mean" was used to denote the perception of mothers to the EPI. A p-value of $<0.05$ was considered statistically significant.

\section{RESULTS AND DISCUSSION}

\subsection{Profile of the Respondents}

In this study, a total of 50 respondents from Ugac Sur, Tuguegarao City, Philippines were included. The mean age of the respondents was $32 \pm 7.19$ years old.

Table 1 shows the characteristics of the respondents based on their compliance status. Among the categorical variables, only 2 variables showed significant correlation with the compliance status of the respondents. This significant association was determined using a Fisher's exact test. It showed that the employment status of the respondents, and the place of vaccination of their children were significantly associated with the compliance of the mothers to childhood immunization.
Table 1. The characteristics of the respondents according to their compliance status.

\begin{tabular}{|c|c|c|c|}
\hline Variable & $\begin{array}{c}\text { Complian } \\
\mathbf{t} \\
\text { (N) }\end{array}$ & $\begin{array}{c}\text { Not } \\
\text { Complian } \\
\mathbf{t} \\
\text { (N) }\end{array}$ & p-value \\
\hline $\begin{array}{l}\text { Marital Status } \\
\text { Single } \\
\text { Married }\end{array}$ & $\begin{array}{l}12 \\
35\end{array}$ & $\begin{array}{l}1 \\
2\end{array}$ & $\mathrm{p}=0.6036$ \\
\hline $\begin{array}{l}\text { Number of } \\
\text { Children } \\
\text { One or } 2 \\
3 \text { or more }\end{array}$ & $\begin{array}{l}31 \\
16\end{array}$ & $\begin{array}{l}3 \\
0\end{array}$ & $\begin{array}{c}\mathrm{p}=0.0305 \\
3\end{array}$ \\
\hline $\begin{array}{l}\text { Educational } \\
\text { Attainment } \\
\text { College } \\
\text { Undergraduate } \\
\text { College } \\
\text { graduate }\end{array}$ & 30 & $\begin{array}{l}1 \\
2\end{array}$ & $\mathrm{p}=0.3119$ \\
\hline $\begin{array}{l}\text { Monthly } \\
\text { Income } \\
\quad<\text { PHP10,000 } \\
\geq \text { PHP10,000 }\end{array}$ & $\begin{array}{l}28 \\
19\end{array}$ & $\begin{array}{l}2 \\
1\end{array}$ & $\mathrm{p}=0.6510$ \\
\hline $\begin{array}{l}\text { Employment } \\
\text { Status } \\
\text { Employed } \\
\text { Unemployed }\end{array}$ & $\begin{array}{l}13 \\
34\end{array}$ & $\begin{array}{l}3 \\
0\end{array}$ & $\begin{array}{c}\mathrm{p}=0.0286 \\
*\end{array}$ \\
\hline $\begin{array}{l}\text { Type of Family } \\
\text { Nuclear } \\
\text { Extended }\end{array}$ & $\begin{array}{l}25 \\
22\end{array}$ & $\begin{array}{l}1 \\
2\end{array}$ & $\mathrm{p}=0.4694$ \\
\hline $\begin{array}{l}\text { Place of } \\
\text { Vaccination } \\
\text { Health Center } \\
\text { Private Clinic }\end{array}$ & $\begin{array}{c}39 \\
8\end{array}$ & $\begin{array}{l}0 \\
3\end{array}$ & $\begin{array}{c}\mathrm{p}=0.0084 \\
*\end{array}$ \\
\hline
\end{tabular}

$*$ p-value $<0.05$ is considered statistically significant

In the present study, the number of compliant mothers who are married is greater than that of the single mothers. However, in this study, there was no significant correlation found between the marital status of the respondents and their compliance to childhood immunization. Nonetheless, various studies found significant association between marital status and vaccination coverage. In fact, in the study of Kim et al (2007), it was noted that single 
motherhood was significantly associated with lower completion rates.

In this study, though majority of the compliant mothers have 1 or 2 children, there was no significant association noted between the number of children and compliance of mothers to childhood immunization. But various studies found inverse relationship between the number of children in the family and the immunization status of their children. In the study of Holipah et al (2018), they were able to observe that mothers with 5 children or more have a lesser likelihood to get their children immunized.

Several studies showed significant association between mother's literacy and vaccination status of their children. In the present study, majority of the mothers who were compliant to their children's immunization were college undergraduate. However, in the present study, there was no noted significant correlation between the educational attainment of the respondents and their compliance to immunization. On the other hand, in the study conducted by Singh et al (2018), in which it was found out that mothers who have completed 12 or more years of education are more likely to have their children fully vaccinated compared to those mothers who have low educational attainment.

Majority of the respondents in this study have a monthly income of less than PHP10,000. In the study conducted by Balogun et al (2017), it was mentioned that household economic status is a significant factor contributing to immunization uptake. Also, some studies revealed that children of parents in higher socioeconomic status are more likely to complete immunization. Conversely, the present study did not show any significant association between monthly income and the compliance of mothers to immunization.

Previous research has shown that unemployed mothers had less likelihood to immunize their children compared to the employed mothers (Subhani et al 2015). In contrast to this, the present study revealed that more than half of the compliant mothers are unemployed $(\mathrm{p}<0.05)$. This finding of the present study was consistent with the finding of Sing et al (2018) and Verulava et al (2019). It was also noted in the present study that all of the mothers who were not compliant to childhood immunization were employed. The non-compliance to immunization of employed mothers may be attributed to the difficulty of getting the immunization done on a fixed date (Sing et al 2018).

A significantly strong association was found between place of vaccination and compliance of mothers to their children's immunization. Majority of the respondents had their children's vaccination at their health center. Only a few mothers opted to bring their children in private clinics for the routine vaccination of their children. Opposite result was observed by Pattnaik et al (2015). In their study, majority of the parents preferred private service providers due to convenient time and place. In the present study, the preference of mothers to health center could be attributed to the accessibility of the place and free vaccination.

\subsection{Extent of Compliance}

Majority (94\%) of the respondents were compliant to their children's immunization. Nonetheless, $6 \%$ of them were found to be non-compliant to the vaccination of their children. These non-compliant mothers mentioned that the reason for their non-compliance to their children's immunization was conflict of schedule. All of the noncompliant mothers were employed ( 2 were private employees and 1 was a vendor), and had difficulty in finding available time for their children's immunization. As such, to be able to cope with this, all of the noncompliant mothers had their children vaccinated in private clinics.

\subsection{Perception of Mothers to EPI}

Table 2. Immunization as a Health Promotion

\begin{tabular}{|l|c|c|}
\hline \multicolumn{1}{|c|}{ HEALTH PROMOTION } & Mean & $\begin{array}{c}\text { Interpretatio } \\
\text { n }\end{array}$ \\
\hline $\begin{array}{l}\text { Children who receive complete } \\
\text { vaccine is healthy and less likely } \\
\text { to get sick }\end{array}$ & 3.9 & $\begin{array}{c}\text { Strongly } \\
\text { Agree }\end{array}$ \\
\hline $\begin{array}{l}\text { Children who received } \\
\text { completed immunization has } \\
\text { stronger immune system }\end{array}$ & 3.8 & $\begin{array}{c}\text { Strongly } \\
\text { Agree }\end{array}$ \\
\hline $\begin{array}{l}\text { Giving immunization at the } \\
\text { right time is more effective in } \\
\text { strengthening the immune } \\
\text { system of the children }\end{array}$ & 3.96 & $\begin{array}{c}\text { Strongly } \\
\text { Agree }\end{array}$ \\
\hline \multicolumn{1}{|c|}{ Average weighted Mean } & 3.88 & Strongly \\
Agree
\end{tabular}

Table 2 illustrates the perception of the respondents on Immunization as health promotion. It shows that the mothers strongly agree that giving immunization at the right time is more effective in strengthening the immune system of their children (3.96), that children who receive complete vaccine is healthy and less likely to get sick (3.9), and that children who received complete immunization has stronger immune system (3.8). 
Table 3. Immunization as a Disease Prevention

\begin{tabular}{|c|c|l|}
\hline DISEASE PREVENTION & $\begin{array}{c}\text { Mea } \\
\mathbf{n}\end{array}$ & $\begin{array}{l}\text { Interpretatio } \\
\mathbf{n}\end{array}$ \\
\hline $\begin{array}{l}\text { Children who has completed } \\
\text { vaccination prevents spread of } \\
\text { communicable diseases }\end{array}$ & 3.9 & $\begin{array}{l}\text { Strongly } \\
\text { agree }\end{array}$ \\
\hline $\begin{array}{l}\text { The more the number of } \\
\text { children who are completely } \\
\text { vaccinated, the lesser the risk of } \\
\text { contracting immunization } \\
\text { preventable diseases. }\end{array}$ & 3.9 & $\begin{array}{l}\text { Strongly } \\
\text { agree }\end{array}$ \\
\hline $\begin{array}{l}\text { Immunization helps in } \\
\text { protecting the child from serious } \\
\text { illnesses. }\end{array}$ & 3.9 & $\begin{array}{l}\text { Strongly } \\
\text { agree }\end{array}$ \\
\hline \multicolumn{1}{|c|}{ Average weighted mean } & 3.9 & $\begin{array}{l}\text { Strongly } \\
\text { agree }\end{array}$ \\
\hline
\end{tabular}

Table 3 illustrates the perception of the respondents on Immunization as disease a prevention. It shows that the mothers strongly agree that children who has completed vaccination prevents spread of communicable diseases (3.9), that the more the number of children who are completely vaccinated, the lesser the risk of contracting immunization preventable diseases (3.9), and that immunization helps in protecting the child from serious illnesses (3.9).

Table 4. Immunization as a Means in Reducing Mortality/Morbidity

\begin{tabular}{|c|c|l|}
\hline \multicolumn{1}{|c|}{ REDUCE } & $\begin{array}{c}\text { Mea } \\
\text { n }\end{array}$ & $\begin{array}{l}\text { Interpretatio } \\
\mathbf{n}\end{array}$ \\
\hline $\begin{array}{l}\text { There is little to no risk of an } \\
\text { epidemic if children have been } \\
\text { immunized. }\end{array}$ & 3.96 & $\begin{array}{l}\text { Strongly } \\
\text { agree }\end{array}$ \\
\hline $\begin{array}{l}\text { Immunization provides an } \\
\text { opportunity to deliver other } \\
\text { lifesaving measures. }\end{array}$ & 3.68 & $\begin{array}{l}\text { Strongly } \\
\text { agree }\end{array}$ \\
\hline $\begin{array}{l}\text { Immunization can prevent death } \\
\text { caused by communicable } \\
\text { diseases. }\end{array}$ & 3.76 & $\begin{array}{l}\text { Strongly } \\
\text { agree }\end{array}$ \\
\hline Average weighted mean & 3.8 & $\begin{array}{l}\text { Strongly } \\
\text { agree }\end{array}$ \\
\hline
\end{tabular}

Table 4 illustrates the perception of the respondents on Immunization as a means in reducing complication or death. It shows that the mothers strongly agree that there is little to no risk of an epidemic if children have been immunized (3.96), that Immunization can prevent death caused by communicable diseases (3.76), and that immunization provides an opportunity to deliver other lifesaving measures (3.68).

\section{CONCLUSION}

Childhood immunization is an important tool in the prevention of many vaccine-preventable diseases. To achieve a high rate of childhood immunization, there must be a concomitant high level of compliance of the mothers. Nonetheless, there are several factors which can influence compliance with immunization that should be considered.

In this study, majority of the mothers were found to be compliant to the immunization program of the Department of Health. This high compliance rate of the mothers may be attributed to the easy access to public health facility (such as health center) and free vaccines in these facilities. It was evident that employment status was significantly associated with the compliance of mothers to childhood immunization. All of the non-compliant mothers were employed and tend to have conflict of schedule with their children's immunization.

Majority of the mothers showed positive perception towards childhood immunization as a health promotion, as a component of disease prevention, and as a factor that alleviates morbidity and mortality from vaccinepreventable diseases. This study revealed that majority of the mothers perceive immunization as an important preventive strategy for their children.

\section{RECOMMENDATION}

This study showed a baseline data on the compliance of mothers to their children's vaccination. It showed that there is a high rate of compliance by the mothers. However, those who were not compliant were found to have difficulty looking for available time for their children to get vaccinated. The researchers therefore would like to recommend to the public health facilities to devise a plan to address this matter.

With the limited number of respondents in the study, the researchers would like to recommend a larger population size for future studies.

The study focused on the perception of the mothers toward immunization. Thus, for future studies, the researchers suggest to use a theory that can cover the practice of the respondents that lead to their behavior in the immunization program.

\section{REFERENCES}

[1] World Health Organization (WHO). 2008. WHO immunization work: 2006-07 highlights. Retrieved from https://apps.who.int/iris/handle/10665/43899. Accessed on 
March 17, 2019

[2] Philippine Statistics Authority (PSA). 2013. Breastfeeding, Immunization and Child Mortality. Retrieved from https://psa.gov.ph/content/breastfeedingimmunization-and-child-mortality. Accessed on March 10, 2019.

[3] UNICEF-WHO Philippines. 2019. Measles outbreak Situation Report 5, 12 March 2019. Retrieved from https://reliefweb.int/report/philippines/unicef-whophilippines-measles-outbreak-situation-report-5-12march-2019. Accessed on March 17, 2019.

[4] World Health Organization (WHO). 2015. Vaccine hesitancy: A growing challenge for immunization programs. Retrieved from http:// www. who.int/ mediacentre/ news/releases/ 2015/ vaccine-hesitancy/en/. Accessed on March 10, 2019.

[5] Damnjanović, K., Graeber, J., Ilić, S., Lam, W. Y., Lep, Ž., Morales, S., Pulkkinen, T., \& Vingerhoets, L. 2018. Parental Decision-Making on Childhood Vaccination. Frontiers in psychology, 9, 735.

[6] Alfred, S. \& Alfred, B.. (2012). Rural Households' Perception of the Expanded Programme on Children Immunization (Epi) in the Southwest of Nigeria.. Greener Journal of Medical Sciences. 2. 012-018. 10.15580/GJMS.2012.1.GJMS1203.

[7] Castillo et al. 2014. Extent of Compliance to Immunization: Reasons for Non-Continuity and Its Consequences. CAM Research Journal Vol 2 No. 1.

[8] Kim, S. S., Frimpong, J. A., Rivers, P. A., \& Kronenfeld, J. J. 2007. Effects of maternal and provider characteristics on up-to-date immunization status of children aged 19 to 35 months. American journal of public health, 97(2), 259266.

[9] Holipah, Maharani, A. \& Kuroda, Y. 2018. Determinants of immunization status among 12- to 23-month-old children in Indonesia (2008-2013): a multilevel analysis. BMC Public Health 18, 288.

[10] Singh J, Deepti SS, Mahajan S, Lal M, Singh T, Neki NS. 2018. Assessment of Socio-demographic factors affecting Immunization status of children of age 0-2 years in Slums of Amritsar city. Int $\mathbf{J}$ of Current Research in Med Sci 4(3): 17-25.

[11] Balogun, S. A., Yusuff, H. A., Yusuf, K. Q., Al-Shenqiti, A. M., Balogun, M. T., \& Tettey, P. 2017. Maternal education and child immunization: the mediating roles of maternal literacy and socioeconomic status. The Pan African medical journal, 26, 217.

[12] Verulava T, Jaiani M, Lordkipanidze A, Jorbenadze R, Dangadze B. 2019. Mothers' Knowledge and attitudes towards child immunization in georgia. Open Public Health J.12(1).

[13] Pattnaik, S., Selvaraj, K., Kumar, G. M., \& Elango, R. 2015. Why do some parents prefer private vaccine providers in urban area?.Journal of Family Medicine and Primary Care, 4(4), 606. 